\title{
Electroliquidation as a Humane Improvement on the Electric Chair
}

\author{
Seun Ayoade* \\ Department of Electrical Engineering, Technician Diploma, London
}

Received: 侮 August 12, 2018; Published: 侮 August 22, 2018

*Corresponding author: Seun Ayoade, Department of Electrical Engineering, Advanced Technician Diploma in Electrical Engineering, City and Guilds, London

\section{Short Communication}

Vaguely referenced in a science fiction novel called Double Bill [1] which was written a few years ago I propose "electro liquidation" as a humane alternative to present methods of capital punishment. Think of electro liquidation as a water locked electric chair. There is no gainsaying that the electric chair in its present form needs improving. The first ever execution by electric chair, 128 years ago, on August 6, 1890 to be precise -was botched. 17 seconds after the chair's powerful electricity had coursed through the murderer's body, two doctors declared the victim dead. And then someone yelled, "Great God, he is alive!" [2] The victim was still breathing and his heart was still beating. It took four minutes for the wife killer named Kemmler to die-and many hours for the corpse to cool off. "They could have done a better job with an axe," critics complained.

Table 1: Method of execution versus average time it takes victims to die [6-8].

\begin{tabular}{|c|c|}
\hline Method & Time it takes for death \\
\hline Ideal electric chair & $\begin{array}{r}\text { unconsciousness in } 0.0042 \text { second [ less than } \\
\text { a second]; painless death soon after }\end{array}$ \\
\hline Electric chair in reality & 2 minutes to 15 minutes \\
\hline $\begin{array}{c}\text { Electroliquidation } \\
\text { [In Theory] }\end{array}$ & $\begin{array}{r}\text { unconsciousness in } 0.0042 \text { second [ less than } \\
\text { a second]; painless death soon after }\end{array}$ \\
\hline Lethal Injection & 10 to 18 minutes \\
\hline Gas chamber & 4 to 11 minutes \\
\hline Hanging & 30 seconds \\
\hline Firing squad & 30 seconds \\
\hline Guillotine & \\
\hline
\end{tabular}

Reading of the event in the newspaper, the electrical wizard Thomas Edison said "The better way is to place the hands in jars of water and let the current be turned on there. Death will be accomplished instantly." Between 1890 and 2010, the United States executed 8,776 people. Of those executions, 276 were bungled in some way. [3] Under normal circumstances the ideal electric chair should cause very swift death. However, the electric chair is far from ideal and has sometimes caused many to suffer burns, smoke inhalation and long agonizing torture. Famous botched electric chair executions include those of Jesse Tafero, Alpha Otis Stephens, Pedro Medina [4] and Fred Van Wormer [5]. I have often wondered why Edison's advice of water-based electrocution was never followed. Now I am advocating what Thomas Edison advocated over 100 years ago-an underwater electric chair- as being the ideal one. I have called the technique "electroliquidation" (Table 1).

The electroliquidation chamber will be a fireproofed Silver or gold plaited tank, with the victim restrained in copper chains/ handcuffs. Brine or saline solution fills the bath/tank which could resemble in appearance a huge bath tub, tanning booth or iron lung. Victim will be supine, head and neck out of water. The electroliquidation chamber could also resemble a glass elevator or escapologist's tank: victim placed vertically or slightly diagonally, head and neck out of water. The wet skin increases the severity of the electric shock. The bottom line is that nearly every botched electric chair execution that has ever taken place occurred because not enough electricity passed through the victim well enough and for long enough.

If these two problems are solved [the quantity, smooth flow and duration] of electricity, the electric chair would work as a charm producing quick, painless death each time it is used. Electroliquidation [in theory] solves these problems. The brine solves sponge problems. The fireproofed/fire resistant silver or gold plaited bath prevents, fire-and the water prevents the corpse from smoldering and being unpresentable. Victims could be anaesthetized before being put in the electroliquidation chamber. As technology improves, remote controlled Nano conductors and Nano generators in the water can be simultaneously impregnated into the victim's vital organs via the skin pores. Brain and organ death will be instantaneous and death completely painless. In summary, electroliquidation is an improvement on the electric chair, an alternative to lethal injection and could and should become the wave of the future. 


\section{References}

1. Seun Ayoade (2014) Double Bill. The 199 Publishing Palace.

2. Michael S Rosenwald (2017) "Great God, he is alive!" The first man executed by electric chair died slower than Thomas Edison expected. April 28, Retropolis, The Washington Post.

3. Gereg Miller (2014) America's gruesome history of botched executions. Lethal Injection, Wired.

4. Associated Press (1997) Condemned Man's Mask Bursts into Flame During Execution. March 26.

\section{(C) This work is licensed under Creative}

To Submit Your Article Click Here: Submit Article

DOI: $10.32474 /$ PRJFGS.2018.02.000126
5. Deborah W Denno (1994) Is Electrocution an Unconstitutional Method of Execution? The Engineering of Death over the Century, 35 Wm \& Mary L Rev 551.

6. U S News (2015) Firing squad to gas chamber: How long do executions take? March 26.

7. Human Rights watch (2008) Electric Chair Banned as Cruel, Unusual Punishment. Nebraska Ruling Brings US Closer to Ending This Inhumane Form of Execution in US.

8. Robert J Sech (1995) Hang 'Em High: A Proposal for Thoroughly Evaluating the Constitutionality of Execution Methods, 30 Val. U. L. Rev 381.

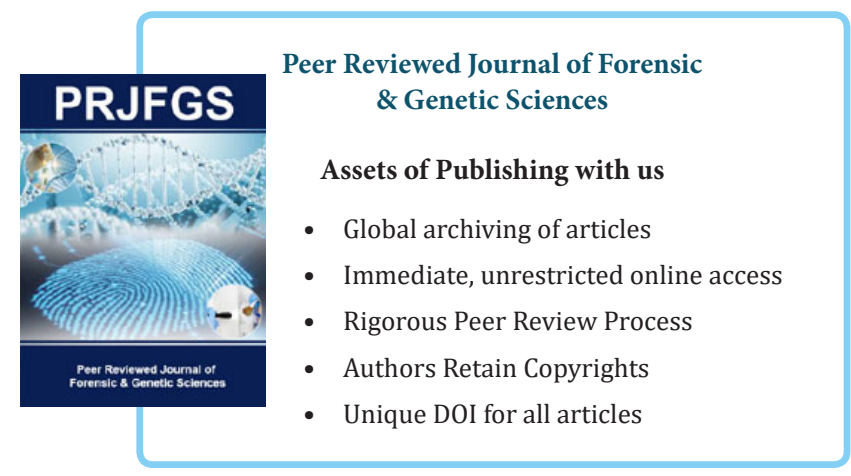

